\title{
Seasonal Fluctuations in Phosphorus Loss by Leaching from a Grassland Soil
}

\author{
Gurpal S. Toor,* Leo M. Condron, Hong J. Di, and Keith C. Cameron
}

\begin{abstract}
Phosphorus losses from soils have been reported to impair the water quality, resulting in deaths of fish and other marine animals, and can harm human health. The objective of this study was to determine the seasonal distribution of $P$ forms and losses in leachate collected from intact soil monoliths (70-cm depth, $50-\mathrm{cm}$ diam.) of a Lismore stony silt loam soil (fine-loamy, mixed, superactive, frigid Aquic Cumulic Hapludoll) during a 2-yr period. The experiment included different combinations of mineral $P$ fertilizer at 45 or $90 \mathrm{~kg}$ $\mathrm{P} \mathrm{ha}^{-1} \mathrm{yr}^{-1}$ and/or farm dairy effluent (FDE) at 200 or $400 \mathrm{~kg} \mathrm{~N} \mathrm{ha}^{-1}$ $\mathrm{yr}^{-1}$, which contained 41 to $95 \mathrm{~kg} \mathrm{P} \mathrm{ha}^{-1} \mathrm{yr}^{-1}$. Amounts and forms of $P$ in leachate collected during the irrigation (IR; November-April) and nonirrigation (NIR; May-October) seasons were compared. Results showed that $P$ losses were higher in particulate forms (mainly particulate unreactive phosphorus, PUP) during the IR seasons. This may be because of regular inputs of high intensity flood IR $(92 \mathrm{~mm}$ per application), which increased the dislocation of particles in the soil profile, thereby resulting in higher PUP losses. On the other hand, the amount of natural rainfall was much lower (usually $<20 \mathbf{~ m m}$ per event) during the NIR seasons that resulted in less dislocation of particles compared with the IR seasons; hence, lower P losses as PUP but higher losses as dissolved unreactive phosphorus (DUP). Variation in $P$ losses during the different seasons suggest the need to develop mitigation strategies that should focus on reducing DUP losses during the NIR and PUP losses during the IR season.
\end{abstract}

$T$ HERE IS a lack of information on seasonal P losses under grassland systems. Studies have suggested that $\mathrm{P}$ losses vary from one event to another depending upon amount, intensity, and duration of rainfall (Edwards and Daniel, 1993; Sharpley, 1997). Studies of this kind are important to understand the mechanisms that promote $\mathrm{P}$ release and its transport to surface and groundwater.

Detailed information on the amounts, forms, and mobility of $\mathrm{P}$ in the soil is required if we are to manage dairy farming systems in an environmentally sustainable way (Toor et al., 2003, 2004a). Phosphorus inputs in the form of mineral $\mathrm{P}$ fertilizer and/or animal manures may be a significant nonpoint source of pollution as a result of P leaching, especially in intensive dairy pastoral systems (Toor et al., 2004b). While it has been reported that $\mathrm{P}$ loss by surface pathways in grassland systems seldom exceeds $2 \mathrm{~kg} \mathrm{ha}^{-1} \mathrm{yr}^{-1}$ (Haygarth and Jarvis, 1999; Hooda et al., 2000; Sharpley and Syers, 1979), this amount can have a significant impact on water quality and use (Condron, 2004; Toor et al., 2003).

Much of the research on $\mathrm{P}$ losses has been on the

G.S. Toor, Dep. of Plant and Soil Sci., Univ. of Delaware, Newark, DE 19716-2170; L.M. Condron, H.J. Di, and K.C. Cameron, Centre for Soil and Environmental Quality, P.O. Box 84, Lincoln Univ., Canterbury, New Zealand. *Corresponding author (gurpal@udel. edu).

Published in Soil Sci. Soc. Am. J. 68:1429-1436 (2004).

(c) Soil Science Society of America

677 S. Segoe Rd., Madison, WI 53711 USA surface pathways because of the widely held supposition that $\mathrm{P}$ is strongly fixed in the soil and does not leach (Sims et al., 1998; Toor et al., 2003, 2004a). However, recently there has been a proliferation of literature on $\mathrm{P}$ leaching losses, although many of these studies have used either small leaching columns or unsealed monoliths. Cameron et al. (1992) have documented that the pattern of water flow and solute losses can be significantly different in unsealed and sealed lysimeters, and the latter gives the best indication of what happens in the field. Hence, there is a need to validate the results from these previous studies.

Moreover, research efforts should distinguish the transport of dissolved and particulate $\mathrm{P}$ in soils, as this will help to identify the transport mechanisms and the fate of $\mathrm{P}$ in the water body. Some workers have proposed that $\mathrm{P}$ loss in particulate forms become dominant during dry summer months, highlighting the importance of preferential flow (e.g., Heathwaite and Dils, 2000; Simard et al., 2000). Approximately 200000 ha of grazed pasture in Canterbury, New Zealand, are currently under spray or flood IR, and this area is expanding rapidly. Most of this grassland is under intensive dairy farming and receives 70 to $120 \mathrm{~mm}$ of IR every 3 to 4 wk during summer to sustain plant growth. It is likely that IR during summer will affect the amounts and forms of $\mathrm{P}$ loss from the soil by leaching. It is therefore important to study this variation so that the management strategies could be targeted at specific $\mathrm{P}$ forms through which $\mathrm{P}$ loss may dominate during a particular season. The objective of this study was to determine the concentrations, amounts, and physicochemical forms of $\mathrm{P}$ in leachate from a grassland soil as influenced by seasonal water inputs.

\section{MATERIALS AND METHODS}

\section{Lysimeter Collection}

Intact monolith lysimeters (70-cm depth, 50-cm diam.) of a free-draining Lismore stony silt loam soil were taken from a permanent grassland site in Canterbury, New Zealand $\left(171^{\circ} 40^{\prime} \mathrm{E}, 44^{\circ} 45^{\prime} \mathrm{S}\right)$, which had been developed under flood IR (border-dyke) with P fertilizer inputs across $50 \mathrm{yr}(0-7.5 \mathrm{~cm}$ : pH 5.9, $36.5 \mathrm{~g} \mathrm{C} \mathrm{kg}^{-1}, 3.53 \mathrm{~g} \mathrm{~N} \mathrm{~kg}^{-1}, 1097 \mathrm{mg} \mathrm{TP} \mathrm{kg}{ }^{-1}, 53 \mathrm{mg}$ Olsen $\mathrm{P} \mathrm{kg}^{-1}$ ). The Lismore soil was developed from moderately weathered greywacke loess over gravels, and the 0 - to 20-, 20- to 40-, and 40- to 60-cm depths contained 10, 14, and $46 \%$ stones $(>2 \mathrm{~mm})$ by volume, respectively. Coarse gravels were predominant below $70 \mathrm{~cm}$. Total phosphorus (TP) concentrations at different depths of Lismore soil have been reported in Sinaj et al. (2002). The land from which the soil

Abbreviations: DRP, dissolved reactive phosphorus; DUP, dissolved unreactive phosphorus; FDE, farm dairy effluent; IR, irrigation; NIR, nonirrigation; PRP, particulate reactive phosphorus; PUP, particulate unreactive phosphorus; TP, total phosphorus; TUP, total unreactive phosphorus. 
monoliths were collected was used for intensive sheep production following the installation of border dyke IR in the 1950s. In 1987 , the property was converted to dairying with consequent increases in stocking rate and fertilizer inputs. The pasture at the site had not been upgraded since the conversion to dairying and was of poor quality with many weeds, so a new pasture with a ryegrass (Lolium perenne L.) and white clover (Trifolium repens L.) mix was established by direct drilling before lysimeter collection in 1998.

The lysimeters were collected according to the method described by Cameron et al. (1992) and laid out in a complete randomized block design with four replicates. In brief, each lysimeter consisted of a steel cylindrical casing which was pushed into the soil to collect an undisturbed soil monolith. A cutting ring at the base of the cylinder created a $0.5-\mathrm{cm}$ annular gap between the soil monolith and the casing, which was filled with liquefied petroleum jelly. Once the jelly solidified, it formed an effective seal to prevent edge flow. The bottom $4 \mathrm{~cm}$ of the soil profile was removed from the cylinder and replaced with a washed gravel and sand mixture to create a free-draining situation similar to that of the field soil.

\section{Lysimeter Treatments and Management}

This study was designed to quantify $\mathrm{P}$ loss by leaching from irrigated grassland soil as influenced by the application of a combination of treatments related to dairying. The lysimeters received different combinations of $\mathrm{P}$ fertilizer, FDE, $\mathrm{N}$ fertilizer (urea), and cow urine across a 2 -yr period (Table 1). Mineral $\mathrm{P}$ fertilizer treatments included $\mathrm{P} 45$, which received superphosphate (20\% potash superphosphate) at $45 \mathrm{~kg} \mathrm{P} \mathrm{ha}^{-1}$ $\mathrm{yr}^{-1}$ in November; and $\mathrm{P} 90 / \mathrm{N} 200 / \mathrm{U}$, which received superphosphate at $90 \mathrm{~kg} \mathrm{P} \mathrm{ha}^{-1} \mathrm{yr}^{-1}$ (split applications in April and November) along with urea at $200 \mathrm{~kg} \mathrm{~N} \mathrm{ha}^{-1} \mathrm{yr}^{-1}$ in four split applications (in February, May, August, and November) and one application of cow urine at $1000 \mathrm{~kg} \mathrm{~N} \mathrm{ha}^{-1} \mathrm{yr}^{-1}$ (to commensurate with a urine patch similar to the field situation). Farm dairy effluent treatments included P45/FDE200, which received superphosphate at $45 \mathrm{~kg} \mathrm{P} \mathrm{ha}^{-1} \mathrm{yr}^{-1}$ along with FDE at $200 \mathrm{~kg} \mathrm{~N} \mathrm{ha}^{-1} \mathrm{yr}^{-1}$ (in four split applications in February, May, August, and November). Similarly, P45/FDE400/U received superphosphate at $45 \mathrm{~kg} \mathrm{P} \mathrm{ha}^{-1} \mathrm{yr}^{-1}$ along with FDE at $400 \mathrm{~kg} \mathrm{~N} \mathrm{ha}^{-1}$ (in four split applications) and one application of cow urine at $1000 \mathrm{~kg} \mathrm{~N} \mathrm{ha}^{-1} \mathrm{yr}^{-1}$. As this study was a part of a larger experiment on $\mathrm{N}$ losses from dairy pastures, some amendments (such as cow urine) were included mainly to study $\mathrm{N}$ loss following their application, as cow urine contains only traces of P (Haynes and Williams, 1993). The total amount of $\mathrm{P}$ applied to lysimeters from $\mathrm{P}$ fertilizer and FDE across 2 $\mathrm{yr}$ is shown in Table 1 . The annual $\mathrm{P}$ fertilizer rate of $45 \mathrm{~kg}$ $\mathrm{ha}^{-1}$ was determined as the amount of $\mathrm{P}$ input required to maintain an Olsen $\mathrm{P}$ of 45 to $50 \mathrm{mg} \mathrm{kg}^{-1}$, which is the optimum level for pasture production under intensive dairy farming in this region of New Zealand.

Flood IR (92 mm per application) was applied every $3 \mathrm{wk}$ (eight applications in a year) during summer and autumn
(November to April). Two FDE (in November and February) and all mineral fertilizer (in November and April) applications occurred during summer and autumn season when IR was also applied. Generally, FDE or mineral P fertilizer was applied at least $1 \mathrm{wk}$ after IR. The lysimeters were managed by cutting the pasture to usual cattle grazing height $(2-3 \mathrm{~cm})$ with electric grass shears when the pasture height was about 25 to $30 \mathrm{~cm}$. This usually occurred every 3 to 4 wk during summer months (November-April) and 4 to 6 wk during winter months (MayOctober).

\section{Leachate Collection}

Leachate was collected from the lysimeters following IR and/or a significant rainfall event during a 2 -yr period in a plastic container, which was connected through a flexible plastic tube to the drainage outlet at the base of each lysimeter. Leachate volume was recorded and a subsample of $250 \mathrm{~mL}$ was taken for analyses. The data set was split into the IR (summer-autumn: November-April) and NIR (winter-spring: May-October) seasons. During the first and second years of the experiment, leachate was collected on 26 (14 IR, 12 NIR) and 25 (10 IR, 15 NIR) occasions, respectively.

\section{Leachate Analysis}

Every leachate sample collected during the 2-yr period was analyzed for different P fractions. Dissolved reactive P (DRP) and total reactive $\mathrm{P}$ (TRP) were measured directly in filtered $(0.45 \mu \mathrm{m})$ and unfiltered leachate samples, respectively, by the malachite green method (Ohno and Zibilske, 1991; van Veldhoven and Mannaerts, 1987). Similarly, total dissolved P (TDP) and TP fractions were determined on filtered $(0.45$ $\mu \mathrm{m})$ and unfiltered samples, respectively, following persulfate digestion (Ebina et al., 1983). The difference in P concentration (arithmetic means) between TDP and TP was assumed to be the concentration of total particulate $\mathrm{P}(>0.45 \mu \mathrm{m})$. Similarly, other P fractions were calculated: TUP (total unreactive phosphorus $)=\mathrm{TP}-\mathrm{TRP}$; DUP $=$ TDP $-\mathrm{DRP}$; $\mathrm{PUP}=$ TUP - DUP; PRP (particulate reactive phosphorus) = TRP - DRP. Sodium inositol hexaphosphate $\left(1 \mathrm{mg} \mathrm{L}^{-1}\right)$ was used as an internal TP standard with each batch of leachate samples.

\section{Phosphorus Loss Calculation}

The P loss from the lysimeters was calculated by multiplying the concentration with the volume of leachate at each sampling time. For the calculation of seasonal losses, values from individual lysimeters were summed for that particular period (NIR or IR) and a mean for the four replicate lysimeters was generated for the different treatments.

\section{Statistical Analysis}

Descriptive statistics was performed by Genstat 4.2, 5th ed. (Lawes Agricultural Trust, Rothamsted, UK) to calculate

Table 1. Annual treatments and total $P$ inputs in the lysimeter experiment.

\begin{tabular}{|c|c|c|c|c|c|c|}
\hline \multirow[b]{2}{*}{ Treatment } & \multirow[b]{2}{*}{ P fertilizer } & \multirow[b]{2}{*}{$\mathbf{N}$ fertilizer } & \multirow[b]{2}{*}{ Urine } & \multirow{2}{*}{$\begin{array}{c}\text { Farm dairy } \\
\text { effluent }\end{array}$} & \multicolumn{2}{|c|}{ Total $P$ inputs } \\
\hline & & & & & 1999-2000 & 2000-2001 \\
\hline & kg P ha $\mathbf{h a}^{-1}$ & 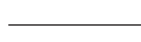 & g N ha & - & $\longrightarrow$ & 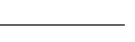 \\
\hline P45 & 45 & - & - & - & 45 & 45 \\
\hline P90/N200/U & 90 & 200 & 1000 & - & 90 & 90 \\
\hline P45/FDE200 & 45 & - & - & 200 & 93 & 86 \\
\hline P45/FDE400/U† & 45 & - & 1000 & $400 \dagger$ & 140 & 104 \\
\hline
\end{tabular}

† Farm dairy effluent application reduced from 400 to $200 \mathrm{~kg} \mathrm{~N} \mathrm{ha}^{-1}$ for the 2000-2001 irrigation season. 
means and standard errors. The LSD test $(P<0.05)$ (with two-way ANOVA in Genstat 4.2) was performed on the seasonal data to test for significance of the effects of season and $\mathrm{P}$ inputs (treatments) on $\mathrm{P}$ concentrations and losses.

\section{RESULTS \\ Drainage from Lysimeters}

Between 45 and $58 \%$ of the total applied water was collected as drainage from the lysimeters of four treatments during different IR and NIR seasons (Table 2). Water inputs were higher during the IR seasons (938$1089 \mathrm{~mm}$ ) than the NIR seasons (548-662 mm), which resulted in significantly $(P<0.05)$ higher drainage during IR (423-599 mm) compared with NIR (262-387 mm), although the percentage of applied water that drained was very similar during both seasons. The lowest drainage from P45/FDE400/U treatment $(277 \mathrm{~mm})$ compared with other treatments $(423-463 \mathrm{~mm})$ during the last IR season (2000-2001) was because of the conversion of this treatment from flood (one application of $92 \mathrm{~mm}$ every $3 \mathrm{wk}$ ) to spray IR (two split applications; total applied water $=92 \mathrm{~mm}$ ).

\section{Seasonal Average Leachate Phosphorus Concentrations}

For the FDE treatments, seasonal TP concentrations were significantly $(P<0.05)$ higher during both IR seasons compared with the corresponding NIR seasons (Table 3). However, for the non-FDE treatments, TP concentrations were not significantly different IR and NIR seasons. The seasonal TP concentrations (averaged across treatments $)$ were significantly $(P<0.05)$ higher during IR than NIR seasons.

\section{Reactive Phosphorus}

Mean DRP concentrations were not significantly $(P<$ $0.05)$ different between IR and NIR seasons for any treatment (Table 3). However, PRP concentrations were significantly $(P<0.05)$ higher for FDE treatments during the IR seasons compared with the NIR seasons, except for the P45/FDE200 treatment (1999-2000). Despite reducing FDE application from 400 to $200 \mathrm{~kg} \mathrm{~N}$ $\mathrm{ha}^{-1} \mathrm{yr}^{-1}$ and applying nearly $40 \mathrm{~kg} \mathrm{P} \mathrm{ha}^{-1}$ less than the previous year in the $\mathrm{P} 45 / \mathrm{FDE} 400 / \mathrm{U}$ treatment during 2000-2001 IR season, PRP concentrations were significantly higher $\left(75 \mu \mathrm{g} \mathrm{L}^{-1}\right)$ than for the NIR season (32 $\mu \mathrm{g} \mathrm{L^{-1 }}$ ).

\section{Unreactive Phosphorus}

Concentrations of DUP were significantly $(P<0.05)$ higher for all the treatments during the 1999 NIR season compared with following IR season (Table 3). However, DUP did not significantly differ during the 2000-2001 IR and NIR seasons, except for the P45/FDE200 treatment. The most abundant $\mathrm{P}$ fraction measured in leachate was PUP with mean concentrations up to $394 \mu \mathrm{g} \mathrm{L}^{-1}$. For the FDE treatments, concentrations of PUP were significantly $(P<0.05)$ higher for both IR seasons compared with NIR. Whereas, for the non-FDE treatments, PUP concentrations were only significantly higher during the first year (1999-2000). Significantly higher PUP concentrations were recorded for the FDE than P45 treatment across respective IR and NIR seasons, except for the P45/FDE200 during the 1999-2000 IR season. When averaged across treatments, seasonal concentrations of DUP and PUP were significantly $(P<0.05)$ higher for the IR than NIR seasons.

\section{Seasonal Amounts of Phosphorus Leached}

A pronounced seasonal variation in TP loss was observed during the 2-yr for all treatments (Table 4). Total $\mathrm{P}$ loss was much higher from FDE treatments (574$1311 \mathrm{~g} \mathrm{ha}^{-1}$ ) compared with non-FDE (148-785 $\left.\mathrm{g} \mathrm{ha}^{-1}\right)$, which was consistent with differences in TP concentrations. Leachate TP loss was significantly $(P<0.05)$ lower from P45 compared with FDE treatments during the different NIR and IR seasons. For non-FDE treatments, TP loss was significantly $(P<0.05)$ higher during both IR seasons (439-785 $\left.\mathrm{g} \mathrm{ha}^{-1}\right)$ compared with the

Table 2. Measured water inputs from rainfall, irrigation, farm dairy effluent, and urine to lysimeters and measured drainage from lysimeters during nonirrigation (NIR) and irrigation (IR) seasons across 2 yr (1999-2000, 2000-2001).

\begin{tabular}{|c|c|c|c|c|}
\hline & \multicolumn{2}{|c|}{$1999-2000 \dagger$} & \multicolumn{2}{|c|}{ 2000-2001+ } \\
\hline & NIR (1999) & IR (1999-2000) & NIR (2000) & IR (2000-2001) \\
\hline \multicolumn{5}{|c|}{ Water input } \\
\hline Rainfall & 504 & 322 & 544 & 106 \\
\hline Irrigation & - & 736 & - & 736 \\
\hline FDE or water $§$ & 44 & 21 & 104 & 86 \\
\hline Urine or water & - & 10 & 14 & 10 \\
\hline Total input & 548 & 1089 & 662 & 938 \\
\hline \multicolumn{5}{|c|}{ Water output } \\
\hline P45 & $262 \pm 10.2(48) \mathrm{a} \rrbracket$ & $588 \pm \overline{10.9(54) b}$ & $366 \pm 17.3(55) c$ & $455 \pm 22.7$ (49)d \\
\hline P90/N200/U & $311 \pm 9.0(57) a$ & $599 \pm 5.1(55) b$ & $335 \pm 3.2$ (51)a & $463 \pm 7.0(49) c$ \\
\hline P45/FDE200 & $303 \pm 7.9(55) a$ & $594 \pm 22.3(55) b$ & $387 \pm 14.4(58) c$ & $423 \pm 9.0(45) c$ \\
\hline P45/FDE400/U & $306 \pm 5.2(56) \mathrm{a}$ & $586 \pm 19.8(54) b$ & $345 \pm 12.5$ (52)ac & $277 \pm 28.4$ (29)ac \\
\hline \multicolumn{2}{|c|}{ LSD $(0.05)($ season $\times$ treatment) } & 48.2 & & \\
\hline
\end{tabular}

† NIR (1999), May-October; IR (1999-2000), November 1999-April 2000.

† NIR (2000), May-October; IR (2000-2001), November 2000-April 2001.

$\S$ In the non-FDE treatments, an equal amount of water (groundwater) was applied at the time of FDE application to FDE treatments so that a similar volume of water is applied in all the lysimeters.

II Mean \pm SE of the mean. Data in parentheses are the percentages of applied water input in each season. Means followed by different letters in the same row are significantly different at $P<0.05$. 
Table 3. Mean concentrations of total $P$, dissolved reactive $P$, particulate reactive $P$, dissolved unreactive $P$, and particulate unreactive $P$ determined in leachate collected from different treatments during nonirrigation (NIR) and irrigation (IR) seasons across 2 yr (1999-2000, 2000-2001).

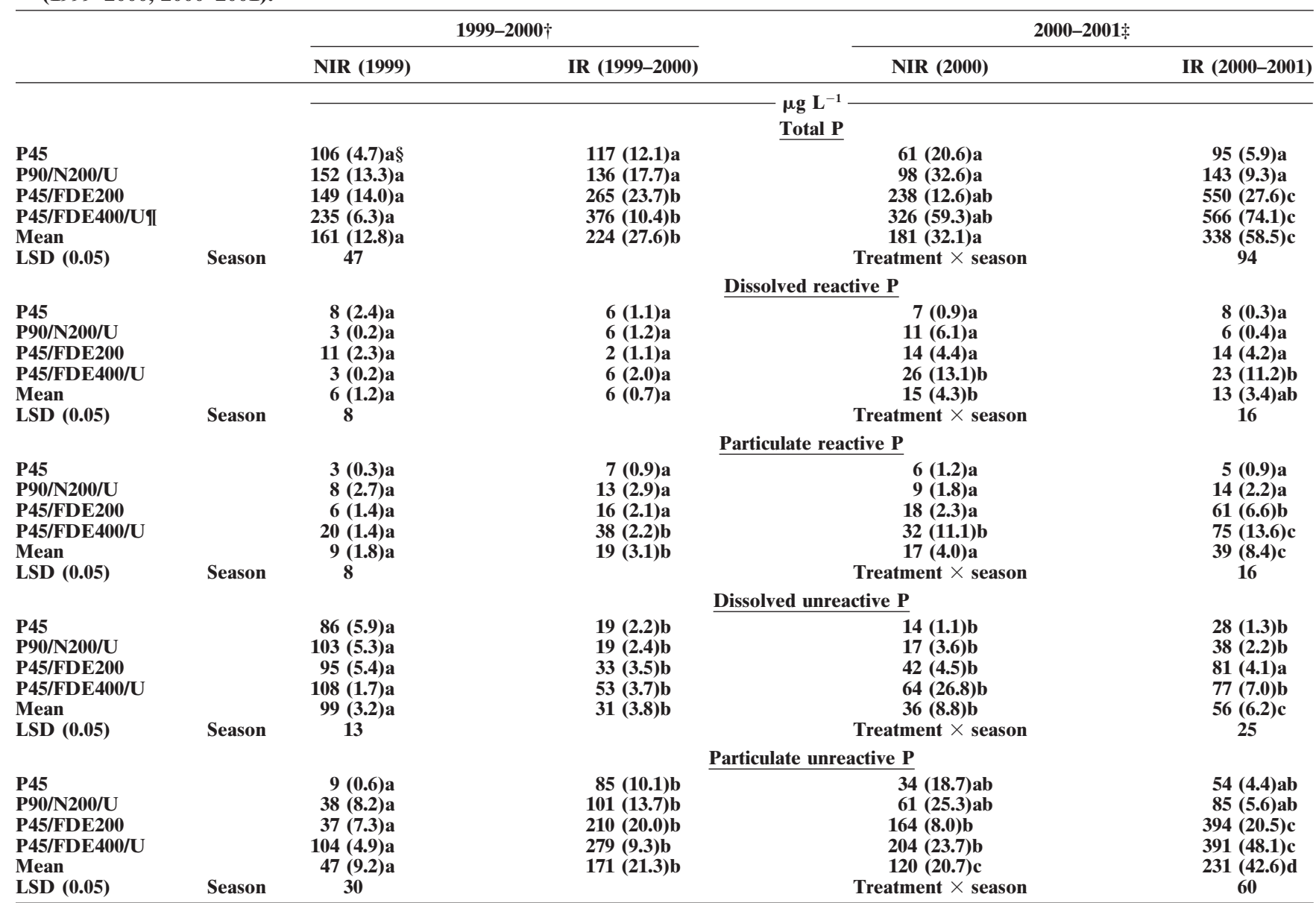

$\dagger$ NIR (1999), May-October; IR (1999-2000), November 1999-April 2000.

+ NIR (2000), May-October; IR (2000-2001), November 2000-April 2001.

$\$$ Data in parentheses are SE of the means. Means followed by different letters in the same row are significantly different at $P<0.05$.

II Farm dairy effluent application reduced from 400 to $200 \mathrm{~kg} \mathrm{~N} \mathrm{ha}^{-1} \mathrm{yr}^{-1}$ for IR (2000-2001).

NIR seasons (148-324 $\left.\mathrm{g} \mathrm{ha}^{-1}\right)$, except for the P90/N200/U treatment during 1999-2000. Similarly, for P45/FDE400/U treatment, TP loss was significantly $(P<0.05)$ higher during the 1999-2000 IR season compared with the previous NIR season. However, during the 2000-2001 season, TP loss significantly decreased from NIR (1300 g $\left.\mathrm{ha}^{-1}\right)$ to IR season $\left(859 \mathrm{~g} \mathrm{ha}^{-1}\right)$ because of reduction in the amount of FDE from 400 to $200 \mathrm{~kg} \mathrm{~N} \mathrm{ha}^{-1} \mathrm{yr}^{-1}$ during the IR season. Total P loss was not significantly $(P<0.05)$ different between IR and NIR seasons for the P45/FDE200 treatment. It should be noted that the FDE was applied four times in a year at three monthly intervals; hence, there were two applications of FDE during the IR or NIR seasons which resulted in a similar amount of TP loss for FDE treatments.

\section{Reactive Phosphorus}

As with the lowest DRP concentrations during the IR and NIR seasons, losses of DRP were lowest among reactive and unreactive $\mathrm{P}$ forms (Table 4$)$. The DRP losses did not significantly $(P<0.05)$ differ between IR and NIR seasons. Reduction of FDE application in the P45/FDE400/U treatment from 400 to $200 \mathrm{~kg} \mathrm{~N} \mathrm{ha}^{-1}$ $\mathrm{yr}^{-1}$ and conversion of this treatment from flood to spray IR during the 2000-2001 IR season likely resulted in significantly $(P<0.05)$ lower DRP loss $\left(23 \mathrm{~g} \mathrm{ha}^{-1}\right)$ compared with the previous NIR season $\left(74 \mathrm{~g} \mathrm{ha}^{-1}\right)$.

Losses of PRP were higher, but not significantly $(P<$ 0.05 ) different, during both IR seasons compared with corresponding NIR seasons (Table 4). The PRP loss increased with the different seasons for FDE treatments; for example, PRP loss was only $23 \mathrm{~g} \mathrm{ha}^{-1}$ from P45/ FDE200 during the 1999 NIR season. This increased to $61 \mathrm{~g} \mathrm{ha}^{-1}$ during the following IR season, followed by 103 and $116 \mathrm{~g} \mathrm{ha}^{-1}$ during the 2000-2001 NIR and IR seasons, respectively. A similar pattern of PRP increase occurred between the 1999 and 2000 NIR seasons for the P45/FDE400/U treatment; however, PRP loss was significantly $(P<0.05)$ lower during the 2000-2001 IR season.

\section{Unreactive Phosphorus}

Losses of DUP were significantly $(P<0.05)$ higher during the 1999-2000 NIR season than the following 
Table 4. Mean cumulative losses of total $P$, dissolved reactive $P$, particulate reactive $P$, dissolved unreactive $P$, and particulate unreactive $P$ determined in leachate collected from different treatments during nonirrigation (NIR) and irrigation (IR) seasons across 2 yr (1999-2000, 2000-2001).

\begin{tabular}{|c|c|c|c|c|c|}
\hline & & \multicolumn{2}{|c|}{ 1999-2000 $\dagger$} & \multicolumn{2}{|c|}{$2000-2001+$} \\
\hline & & NIR (1999) & IR (1999-2000) & NIR (2000) & IR (2000-2001) \\
\hline & & \multicolumn{4}{|c|}{$-\mathbf{g} \mathbf{h a}^{-1}$} \\
\hline & & \multicolumn{4}{|c|}{ Total P } \\
\hline P45 & & 324 (18.6)ac§ & $615(21.1) b$ & $148(16.0) a$ & $439(47.1) b c$ \\
\hline P90/N200/U & & 537 (48.3)a & 785 (101.9)a & 208 (38.8)b & 675 (42.5)a \\
\hline P45/FDE200 & & 574 (54.9)a & 788 (60.5)a & $1250(119.5) b$ & $1289(67.9) \mathrm{b}$ \\
\hline P45/FDE400/UI & & $896(32.3) a$ & $1311(45.9) \mathrm{b}$ & 1300 (329.8)b & $859(59.8) a$ \\
\hline Mean & & $584(55.1) a$ & $875(72.8) b$ & 727 (163.3)ac & $817(82.5) b c$ \\
\hline \multirow[t]{2}{*}{ LSD (0.05) } & Season & 164 & & Treatment $\times$ season & 272 \\
\hline & & \multicolumn{4}{|c|}{ Dissolved reactive $\mathbf{P}$} \\
\hline P45 & & $22(8.2) a$ & $18(3.7) a$ & $16(2.7) \mathrm{a}$ & $38(3.3) a$ \\
\hline P90/N200/U & & $8(0.5) a$ & 16 (2.8)a & 16 (4.8)a & 25 (3.2)a \\
\hline P45/FDE200 & & 36 (7.7)a & $24(7.2) a$ & 42 (10.8)a & 69 (27.8)a \\
\hline P45/FDE400/U & & 8 (0.6)a & 22 (7.9)a & 74 (42.7)b & $23(5.0) a$ \\
\hline Mean & & $19(4.0) \mathrm{a}$ & $19(3.0) \mathrm{a}$ & $37(12.6) a$ & 39 (8.5)a \\
\hline \multirow[t]{2}{*}{ LSD (0.05) } & Season & 23 & & Treatment $\times$ season & 45 \\
\hline & & \multicolumn{4}{|c|}{$\underline{\text { Particulate reactive } \mathbf{P}}$} \\
\hline P45 & & $11(0.6) a$ & 39 (3.6)a & $15(1.5) a$ & $23(4.9) \mathrm{a}$ \\
\hline P90/N200/U & & 33 (11.6)a & $69(17.3) a$ & 28 (3.5)a & 64 (7.8)a \\
\hline P45/FDE200 & & 23 (6.2)a & $61(5.6) \mathrm{ac}$ & 103 (16.2)bc & $116(5.9) b$ \\
\hline P45/FDE400/U & & 85 (8.4)a & 108 (3.9)ac & $141(55.4) b c$ & $87(8.0) a c$ \\
\hline Mean & & 38 (8.0)a & $71(7.8) b$ & 72 (19.5)b & $73(9.2) \mathrm{b}$ \\
\hline \multirow[t]{2}{*}{ LSD (0.05) } & Season & 26 & & Treatment $\times$ season & 53 \\
\hline & & \multicolumn{4}{|c|}{ Dissolved unreactive $\mathbf{P}$} \\
\hline P45 & & $266(18.5) a$ & $103(6.6) b$ & $52(3.8) b$ & $132(14.4) b$ \\
\hline P90/N200/U & & 347 (23.1)a & 114 (13.1)bd & $47(5.2) \mathrm{b}$ & 179 (8.1)cd \\
\hline P45/FDE200 & & $353(20.3) a$ & 153 (15.4)b & $201(39.3) b$ & $247(20.5) b$ \\
\hline P45/FDE400/U & & 382 (9.1)a & $201(3.8) b$ & 268 (131.4)b & $156(14.0) b$ \\
\hline Mean & & 337 (14.2)a & 143 (11.1)b & $142(41.8) b$ & $179(13.0) b$ \\
\hline \multirow[t]{2}{*}{ LSD (0.05) } & Season & 60 & & Treatment $\times$ season & 121 \\
\hline & & \multicolumn{4}{|c|}{ Particulate unreactive $\mathbf{P}$} \\
\hline P45 & & $25(3.2) \mathrm{a}$ & 455 (21.6)b & $65(15.2) a$ & $246(29.7) c$ \\
\hline P90/N200/U & & 149 (35.1)a & $586(74.3) b$ & 117 (28.5)a & $407(30.7) c$ \\
\hline P45/FDE200 & & $162(38.0) a$ & $550(35.3) \mathrm{b}$ & $904(71.0) c$ & 857 (31.2)c \\
\hline P45/FDE400/U & & 421 (23.5)a & $980(47.1) \mathrm{b}$ & 817 (112.3)b & $593(45.6) c$ \\
\hline Mean & & $190(38.8) a$ & $641(55.7) b$ & $476(102.6) c$ & $526(59.4) c$ \\
\hline LSD (0.05) & Season & 78 & & Treatment $\times$ season & 156 \\
\hline
\end{tabular}

$\dagger$ NIR (1999), May-October; IR (1999-2000), November 1999-April 2000.

† NIR (2000), May-October; IR (2000-2001), November 2000-April 2001.

$\S$ Data in parentheses are standard errors of the means. Means followed by different letters in the same row are significantly different at $P<0.05$.

II Farm dairy effluent application reduced from 400 to $200 \mathrm{~kg} \mathrm{~N} \mathrm{ha}^{-1} \mathrm{yr}^{-1}$ for IR (2000-2001).

IR season for all treatments (Table 4). However, DUP losses were not significantly different during the 2000$2001 \mathrm{yr}$, except for the P90/N200/U treatment. Consistent with the higher PUP concentrations than other P forms, PUP loss was significantly $(P<0.05)$ higher from non-FDE treatments for both IR seasons $(246-586 \mathrm{~g}$ $\mathrm{ha}^{-1}$ ) compared with the previous NIR seasons (25$149 \mathrm{~g} \mathrm{ha}^{-1}$ ). Similarly, for FDE treatments, PUP loss was two- to three-fold higher for the 1999-2000 IR than for the previous NIR season. However, losses of PUP were significantly lower during the 2000-2001 IR season $\left(593 \mathrm{~g} \mathrm{ha}^{-1}\right)$ than the previous NIR season $\left(817 \mathrm{~g} \mathrm{ha}^{-1}\right)$ for the P45/FDE400/U treatment. When averaged across treatments, losses of PUP were only significantly $(P<$ 0.05) different during 1999-2000 IR and NIR season.

\section{DISCUSSION}

\section{Forms of Phosphorus in Leachate}

In leachate collected from lysimeters during the $2 \mathrm{yr}$, unreactive $\mathrm{P}$ forms (DUP, PUP) represented 77 to $91 \%$ of TP, with the remaining as reactive P (DRP, PRP)
(Fig. 1). These observations are consistent with the findings of Chardon et al. (1997), who investigated the effects of swine (Sus domesticus) slurry application to a sandy soil in The Netherlands. Their results showed that unreactive $\mathrm{P}$ represented 70 to $90 \%$ of TP in leachate collected from lysimeters. They suggested that unreactive forms of $\mathrm{P}$ are less strongly sorbed in the soil, and hence, have higher mobility in the soil profile and escape to waters (Rolston et al., 1975). Information on the specific P forms constituting the PUP is very limited, but probably represent $\mathrm{P}$ held within soil particles, complexes of clay and organic matter with organic $\mathrm{P}$, and bacterial cell debris (Hannapel et al., 1964). Toor et al. (2003) suggested that PUP may include inositol hexakisphosphate, while sugar phosphates and diesters (nucleic acids and phospholipids) may be a part of DUP. The relative lower losses in reactive $\mathrm{P}$ forms indicate adsorption onto soil colloid surfaces (Frossard et al., 2000). In a laboratory study, Frossard et al. (1989) noted that organic P species (adenosine triphosphate, choline phosphate, and glucose-6-phosphate) were less strongly adsorbed onto soil colloids than inorganic P. Other re- 
(a) NIR (1999)

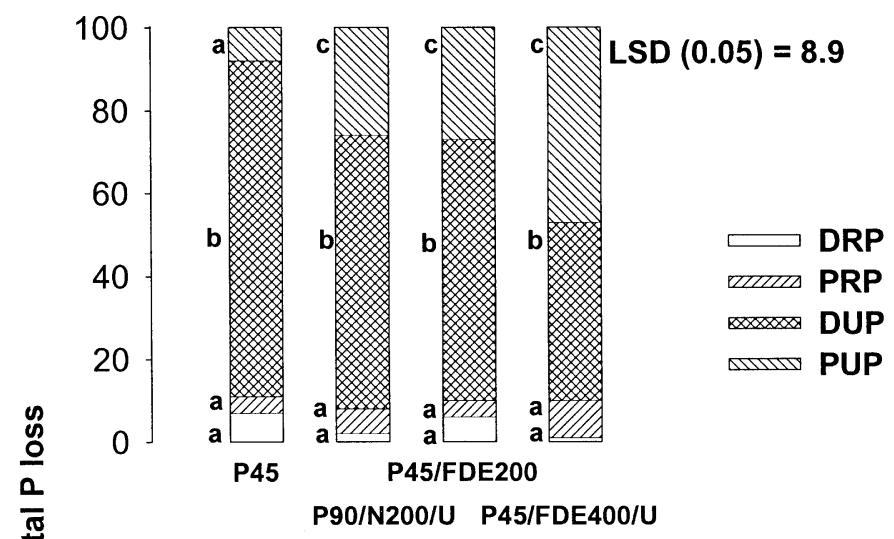

(b) IR (1999-2000)

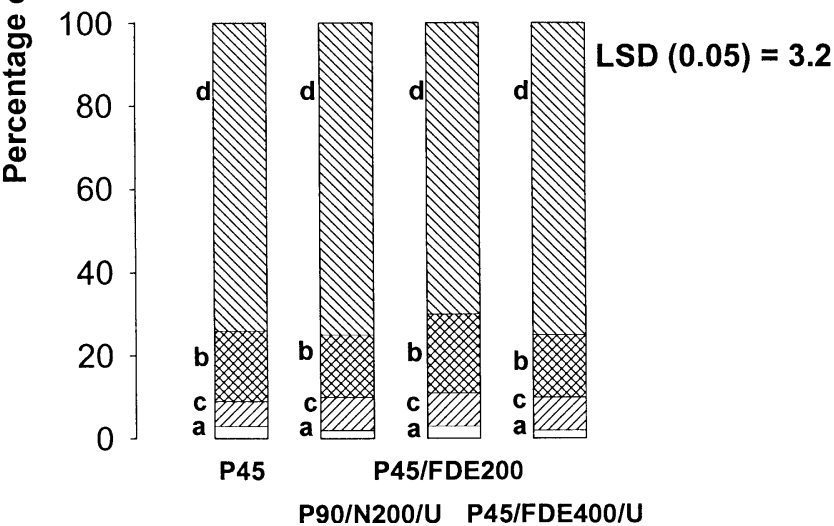

(c) NIR (2000)

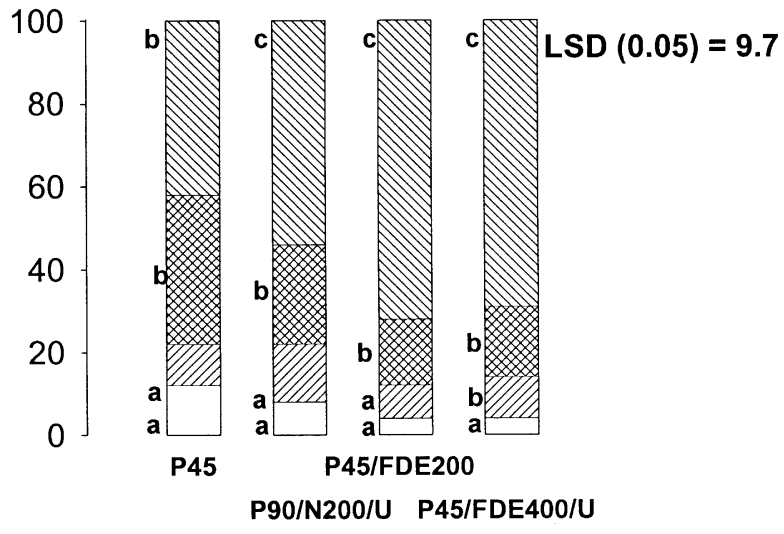

(d) IR (2000-2001)

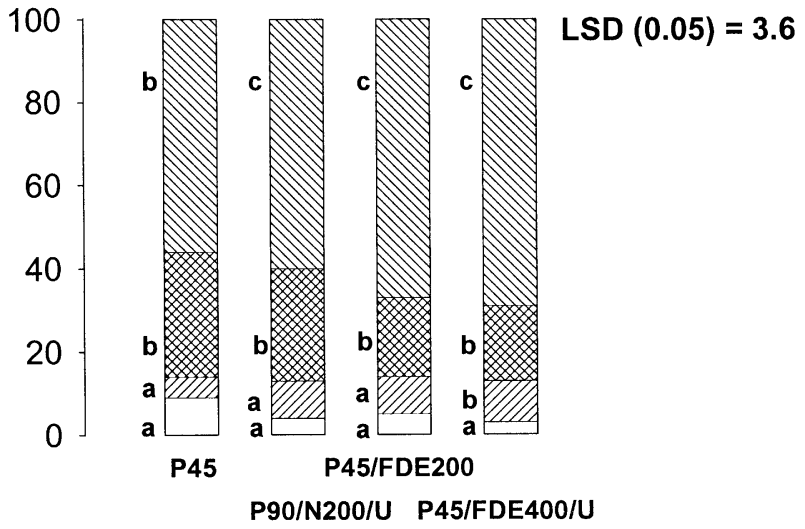

Fig. 1. Percentage of total $P$ losses determined as dissolved reactive $P$ (DRP), particulate reactive $P$ (PRP), dissolved unreactive $P$ (DUP), and particulate unreactive $P$ (PUP) in leachate collected from different treatments during (a and c) nonirrigation (NIR) and (b and d) irrigation (IR) seasons (1999-2000, 2000-2001). Percentage means of $P$ forms followed by different letters in the same bar are significantly different at $P<0.05)$.

searchers (e.g., Ron Vaz et al., 1993) also highlighted the importance of unreactive $\mathrm{P}$ forms in $\mathrm{P}$ leaching. The results of the present study support these findings but are in contrast to the observations of Turner and Haygarth (2000), who reported a dominance of reactive P forms $\left(28-86 \mu \mathrm{g} \mathrm{L}^{-1}\right)$ over unreactive $\mathrm{P}$ forms (13-50 $\mu \mathrm{g} \mathrm{L}^{-1}$ ) in leachate from four grassland soils in England. These differences are possibly because of one or more of the following reasons: (i) no animal slurry was added in their experiment, (ii) the soils used in the present study are stony and free-draining, and (iii) flood IR was applied during the summer months in the present study. In our previous report (Sinaj et al., 2002), we observed that the presence of higher amounts of $\mathrm{Fe}$ and $\mathrm{Al}$ oxides and hydroxides in the subsoil of Lismore soil was responsible for fixing reactive $\mathrm{P}$ that was mobilized from the surface horizons. This resulted in considerably lower leaching losses of $\mathrm{P}$ in reactive forms.

Although unreactive and reactive $\mathrm{P}$ concentrations were approximately two-fold higher from FDE than from non-FDE treatments, their relative proportions as percentage of TP were very similar for FDE (TUP, 86-90\%; TRP, 10-14\%) and non-FDE (TUP, 77-91\%; TRP, 9-23\%) treatments. A higher proportion of unreactive $\mathrm{P}(77-91 \%)$ than reactive $\mathrm{P}(9-23 \%)$ from nonFDE treatments suggests that applied fertilizer P was quickly fixed in the soil, whereas organic $\mathrm{P}$ forms present in soil were more amenable to loss even though no fresh addition of unreactive $P$ was made. Chardon et al. (1997) found that unreactive $\mathrm{P}$ in leachate from lysimeters that received either only mineral fertilizer or swine slurry was $>70 \%$ of TP.

\section{Seasonal Patterns}

There was a clear seasonal pattern of the $\mathrm{P}$ losses as dissolved (DRP, DUP) and particulate (PRP, PUP) forms. The proportion of particulate $\mathrm{P}$ forms (mainly PUP) was significantly $(P<0.05)$ higher during the IR season (1999-2000, 70-75\% of TP) compared with the NIR season (1999-2000, 8-47\% of TP) (Table 4, Fig. 1). This indicates the potential for preferential transport of particulate $\mathrm{P}$ in the stony, free-draining Lismore soil under flood IR. Heathwaite and Dils (2000) observed the highest $\mathrm{P}$ concentrations in macropore flow during the summer months. Cooke (1976) attributed higher particulate $\mathrm{P}$ losses in the first drainage water after dry weather to the washing of fine material from the side of fissures and large soil aggregates. Annual losses of particulate $\mathrm{P}$ forms (PUP + PRP) were two-fold higher from FDE (796-1980 $\mathrm{g} \mathrm{ha}^{-1}$ ) than non-FDE treatments (349-837 $\mathrm{g} \mathrm{ha}^{-1}$ ). Magid et al. (1999) suggested that spe- 
cial attention should be given to particulate $\mathrm{P}$ contained in cattle manure remnants lying on the surface that may be directly transported through macropores. Losses of dissolved $\mathrm{P}$ forms (DUP, DRP) were significantly $(P<$ 0.05 ) lower than the particulate P forms (mainly PUP) for all seasons (Fig. 1). A dominance of particulate over dissolved forms may be also because of the quick fixation of $\mathrm{P}$ present in the dissolved forms, whereas particulate forms escape from fixation reactions and are easily transported in the soils. Turner and Haygarth (2000) suggested that the physical detachment of particles from the walls of macropores was responsible for higher $\mathrm{P}$ losses in particulate forms from grassland soils in the UK. Some researchers have reported a dominance of dissolved over particulate P (e.g., Culley et al., 1983; Heckrath et al., 1995; Jordan and Smith, 1985). However, in most of the studies, particulate $\mathrm{P}$ forms were the dominant fractions transported through soils, especially in grasslands (e.g., Hanway and Laflen, 1974; Haygarth et al., 1998; Heathwaite and Dils, 2000; Sharpley and Syers, 1979; Simard et al., 2000). It is believed that soil under grasslands have a larger proportion of macropores than under arable farming, hence is more susceptible to preferential flow. Heathwaite and Dils (2000) noted that $68 \%$ of TP transported in macropore flow through the grassland soils was in the particulate fraction. Simard et al. (2000) also suggested that P loss in the particulate form is important in soils having large amounts of macropores because they are more prone to P loss by preferential pathways. Toor (2002) highlighted the importance of preferential flow in the Lismore soils, where $60 \%$ of TP loss occurred immediately following the application of FDE.

\section{The Influence of Farm Dairy Effluent on Phosphorus Leaching}

The proportion of PUP losses was significantly $(P<$ 0.05 ) higher than DUP for all treatments during all seasons (Fig. 1). Higher PUP concentrations for FDE treatments were because of the regular additions of FDE which contained $32 \%$ of TP as PUP and only $1 \%$ as DUP (Toor, 2002; Toor et al., 2004a), and provided a long term source of particulate P. During the IR seasons, the concentrations and losses of PUP were significantly $(P<0.05)$ higher from FDE than non-FDE treatments, but the relative proportion of particulate $P$ forms was only slightly different between FDE and non-FDE treatments (Tables 3 and 4; Fig. 1). This shows the susceptibility of these soils to preferential flow during the IR seasons and the importance of high intensity IR that can dislocate soil particles. Additionally, regular inputs of water, together with the higher temperatures prevailing during the summer months (IR season), may promote wetting and drying cycles which may result in flushes of microbial $\mathrm{P}$ through lysis of desiccated cells by rewetting (Kieft et al., 1987; Salema et al., 1982; Turner and Haygarth, 2000, 2001). Then, this pool of microbially released $\mathrm{P}$ may have been intercepted by mobilized particles (added with FDE) in the soil profile that culminated in higher losses as PUP. However, dur- ing the NIR seasons, the relative proportion of PUP was much higher for FDE treatments $(69-75 \%$ of TP) compared with non-FDE treatments (8-54\%). As FDE was applied at regular intervals throughout the year, it was a potential source of particulates even during NIR seasons, which resulted in higher PUP losses from FDE treatments. Lower P losses as PUP from the non-FDE treatments during NIR seasons are because of the lower amounts of natural rainfall (usually $<20 \mathrm{~mm}$ per event), which restricted the dislocation and movement of soil particles. This resulted in higher losses as DUP during the NIR seasons compared with IR seasons (Fig. 1).

Proportion of DRP and PRP fractions was $<10 \%$ of TP during the first year (1999-2000) and between 11 and $23 \%$ of TP during the second year of experiment (Fig. 1). Concentrations of DRP were very similar for the FDE and non-FDE treatments for the first year despite the regular addition of DRP from FDE in the FDE treatments. On the other hand, PRP concentrations were higher from the FDE treatments than nonFDE treatments. Lower losses of DRP from FDE treatments confirm the relative ability of these soils to quickly sorb P present as DRP; however, PRP, being in the particulate phase $(>0.45 \mu \mathrm{m})$, escaped from sorption reactions. In England, Chalmers and Withers (1998) reported that concentrations of DRP in leachate samples collected from a $0.3-\mathrm{m}$ soil depth with Teflon (DuPont, Wilmington, DE) suction cups over three winter seasons decreased with the increasing depth because of P sorption effects. Higher concentrations of PRP during the IR seasons compared with the NIR seasons may be attributed to the rapid transport of PRP in soil profile through macropores during the IR season.

This study demonstrated a clear difference in the amounts and forms of P loss from soil under IR compared with natural rainfall. Significantly $(P<0.05)$ higher P losses were observed for the FDE treatments compared with non-FDE (e.g., P45 treatment). For all treatments, higher $\mathrm{P}$ losses were recorded in particulate $\mathrm{P}$ forms (mainly PUP) during the IR season because of the addition of high volume artificial IR $(92 \mathrm{~mm}$ per event), while dissolved $\mathrm{P}$ forms (mainly DUP) dominated during NIR season in non-FDE treatments. The consistent lower concentrations of DRP measured from different treatments suggest the higher capacity of these soils to rapidly retain P present as DRP.

\section{ACKNOWLEDGMENTS}

This research was supported by the New Zealand ViceChancellors' Committee through its Commonwealth Scholarship program to the senior author. Funding for the establishment of lysimeter experiment was provided by Ravensdown Fertilizer Co-operative Limited and the New Zealand Fertilizer Manufacturers' Research Association. The authors would like to thank Trevor Hendry of Lincoln University for his help with lysimeter sampling and leachate collection.

\section{REFERENCES}

Cameron, K.C., N.P. Smith, C.D.A. McLay, P.M. Fraser, R.J. McPherson, D.F. Harrison, and P. Harbottle. 1992. Lysimeters without 
edge-flow: An improved design and sampling procedure. Soil Sci. Soc. Am. J. 56:1625-1628.

Chalmers, A.G., and P.J.A. Withers. 1998. Phosphorus leaching from soils enriched with phosphorus loadings from organic manures. $p$. 144-145. In Practical and Innovative Measures for the Control of Agricultural Phosphorus Losses to Water Conf., 2nd, Antrim, Northern Ireland. 16-19 June 1998. Greenmount College of Agriculture and Horticulture, Antrim.

Chardon, W.J., O. Oenema, P. Delcastilho, R. Vriesema, J. Japenga, and D. Blaauw. 1997. Organic phosphorus in solutions and leachates from soils treated with animal slurries. J. Environ. Qual. 26: 372-378.

Condron, L.M. 2004. Phosphorus-Surplus and deficiency. p. 69-84. In P. Schjonning et al. (ed.) Managing soil quality-Challenges in modern agriculture. CAB International, Wallingford, UK.

Cooke, G.W. 1976. A review of the effects of agriculture on the chemical composition and quality of surface and underground waters. p. 5-73. In MAFF Tech. Bull. 32. H.M. Stationery Office, London.

Culley, J.L.B., E.F. Bolton, and V. Bernyk. 1983. Suspended soils and phosphorus loads from a clay loam: 1. Plot studies. J. Environ. Qual. 12:493-498.

Ebina, J.T., T. Tsutsui, and T. Shirai. 1983. Simultaneous determination of total nitrogen and total phosphorus in water using peroxodisulfate oxidation. Water Res. 17:1721-1726.

Edwards, D.R., and T.C. Daniel. 1993. Effects of litter application rate and rainfall intensity on quality of runoff from fescue grass plots. J. Environ. Qual. 22:361-365.

Frossard, E., L.M. Condron, A. Oberson, S. Sinaj, and J.C. Fardeau. 2000. Processes governing phosphorus availability in temperate soils. J. Environ. Qual. 29:15-23.

Frossard, E., J.W.B. Stewart, and R.J. St. Arnaud. 1989. Distribution and mobility of phosphorus in grassland and forest soils of Saskatchewan. Can. J. Soil Sci. 69:401-416.

Hannapel, R.J., W.H. Fuller, and R.H. Fox. 1964. Phosphorus movement in a calcareous soil: II. Soil microbial activity and organic phosphorus movement. Soil Sci. 97:421-427.

Hanway, J.J., and J.M. Laflen. 1974. Plant nutrient losses from tileoutlet terraces. J. Environ. Qual. 3:351-356.

Haygarth, P.M., L. Hepworth, and S.C. Jarvis. 1998. Forms of phosphorus transfer in hydrological pathways from soil under grazed grassland. Eur. J. Soil Sci. 49:65-72.

Haygarth, P.M., and S.C. Jarvis. 1999. Transfer of phosphorus from agricultural soils. Adv. Agron. 66:195-249.

Haynes, R.J., and P.H. Williams. 1993. Nutrient cycling and soil fertility in the grazed pasture ecosystem. Adv. Agron. 49:119-199.

Heathwaite, A.L., and R.M. Dils. 2000. Characterising phosphorus loss in surface and subsurface hydrological pathways. Sci. Total Environ. 251:523-538.

Heckrath, G., P.C. Brookes, P.R. Poulton, and K.W.T. Goulding. 1995. Phosphorus leaching from soils containing different phosphorus concentrations in the Broadbalk Experiment. J. Environ. Qual. 24:904-910.

Hooda, P.S., A.C. Edwards, H.A. Anderson, and A. Miller. 2000. A review of water quality concerns in livestock farming areas. Sci. Total Environ. 250:143-167.

Jordan, C., and R.V. Smith. 1985. Factors affecting leaching of nutri- ents from an intensively managed grassland in County Antrim, Northern Ireland. J. Environ. Manage. 20:1-15.

Kieft, T.L., E. Soroker, and M.K. Firestone. 1987. Microbial biomass response to a rapid increase in water potential when dry soil is wetted. Soil Biol. Biochem. 19:119-126.

Magid, J., M.B. Jensen, T. Mueller, and H.C.B. Hansen. 1999. Phosphate leaching responses from unperturbed, anaerobic, or cattle manured mesotrophic sandy loam soils. J. Environ. Qual. 28:17961803.

Ohno, T., and L.M. Zibilske. 1991. Determination of low concentrations of phosphorus in soil extracts using malachite green. Soil Sci. Soc. Am. J. 55:892-895.

Rolston, D.E., R.S. Rauschkolb, and D.L. Hoffman. 1975. Infiltration of organic phosphate compounds in soil. Soil Sci. Soc. Am. Proc. 39:1089-1094.

Ron Vaz, M.D., A.C. Edwards, C.A. Shand, and M.S. Cresser. 1993. Phosphorus fractions in soil solution: Influence of soil acidity and fertiliser additions. Plant Soil 148:175-183.

Salema, M.P., C.A. Parker, D.K. Kidby, D.L. Chatel, and T.M. Armitage. 1982. Rupture of nodule bacteria on drying and rehydration. Soil Biol. Biochem. 14:15-22.

Sharpley, A.N. 1997. Rainfall frequency and nitrogen and phosphorus runoff from soil amended with poultry litter. J. Environ. Qual. 26:1127-1132.

Sharpley, A.N., and J.K. Syers. 1979. Loss of nitrogen and phosphorus in tile drainage as influenced by urea application and grazing animals. N. Z. J. Agric. Res. 22:127-131.

Simard, R.R., S. Beauchemin, and P.M. Haygarth. 2000. Potential for preferential pathways of phosphorus transport. J. Environ. Qual. 29:97-105.

Sims, J.T., R.R. Simard, and B.C. Joern. 1998. Phosphorus loss in agricultural drainage-Historical perspective and current research. J. Environ. Qual. 27:277-293.

Sinaj, S., C. Stamm, G.S. Toor, L.M. Condron, T. Hendry, H.J. Di, K.C. Cameron, and E. Frossard. 2002. Phosphorus exchangeability and leaching losses from two grassland soils. J. Environ. Qual. 31:319-330.

Toor, G.S. 2002. Phosphorus leaching losses from an irrigated freedraining soil under dairying. Ph.D. thesis. Lincoln Univ., Canterbury, New Zealand.

Toor, G.S., L.M. Condron, B.J. Cade-Menun, H.J. Di, and K.C. Cameron. 2004a. Preferential phosphorus leaching from an irrigated grassland soil. Eur. J. Soil Sci. (in press).

Toor, G.S., L.M. Condron, H.J. Di, K.C. Cameron, and B.J. CadeMenun. 2003. Characterization of organic phosphorus in leachate from a grassland soil. Soil Biol. Biochem. 35:1317-1323.

Toor, G.S., L.M. Condron, H.J. Di, K.C. Cameron, and J.T. Sims. 2004b. Assessment of phosphorus leaching losses from a free draining grassland soil. Nutr. Cycling Agroecosyst. 69:(in press).

Turner, B.L., and P.M. Haygarth. 2000. Phosphorus forms and concentrations in leachate under four grassland soil types. Soil Sci. Soc. Am. J. 64:1090-1099.

Turner, B.L., and P.M. Haygarth. 2001. Phosphorus solubilisation in rewetted soils. Nature (London) 411:258.

van Veldhoven, P.P., and G.P. Mannaerts. 1987. Inorganic and organic phosphate measurements in the nanomolar range. Anal. Biochem. 161:45-48. 